\title{
Informal Employment Re-loaded
}

\author{
Johannes Jütting, Jante Parlevliet and Theodora Xenogiani*
}

\begin{abstract}
1 Introduction: competing views on the informal economy

The informal sector, informality and informal employment has been debated since the early seventies when it was initiated at the launch of the ILO World Employment Programme, the publication of the Kenya Report (1972) and the seminal contribution by Hart (1973). More than three decades later, some progress has been made in defining and measuring the 'Informal Sector Elephant' (Mead and Morrisson 1996). Much less has been achieved when it comes to understanding the persistence of informality and what this means for policymaking (Maloney 2004).
\end{abstract}

In recent years there has been renewed interest by the policy community in the relationship between employment, development and poverty reduction. One important outcome of the various 'pro-poorgrowth studies' is the identification of the employment sector as key for transforming growth into effective poverty reduction (OECD 2006; Osmani 2005; Islam 2004; Lundström and Ronnås 2006). Based on these results, policymakers are looking for new insights and advice how to transform growth into more and better jobs.

In policy circles, there exists still the widely held belief that those people working informally are forced to do so to ensure a minimum standard of living of their family. Jobs in the informal economy are characterised by 'very poor working conditions and low earnings and with no or little social protection' (EC 2007). On the research side, there is a long-standing view that sees informal employment as the product of the rationing of jobs in dualistic labour markets. Secure, well-paid jobs are supposed to be in the formal sector, while the informal sector is characterised as small-scale activity, often not legal, with low productivity and low wages (Lewis 1954; Harris and Todaro 1970).
This view has been challenged by those who argue that informal employment is a voluntary utilitymaximising choice on the part of individuals (Gindling 1991; Maloney 2004). People opt to work informally because, after weighing cost and benefits, they find that they are better off than working in the formal sector. Recently, a third view has emerged combining aspects of both. Fields (2005) and others argue that in urban informal labour markets in developing countries there exists an 'upper-tier' and 'lower-tier'. The 'upper tier' comprises the competitive part, i.e. those who voluntarily choose to be informal and the 'lower tier' consists of individuals who cannot afford to be unemployed but have no hope of ever getting a formal job. This suggests interesting new interpretation of individuals' motivation to stay informal and has important policy implications. This article seeks to challenge conventional thinking about informal employment by examining characteristics and trends in informal employment more generally (Section 2) and in relation to case study findings from China and Mexico (Section 3). Section 4 highlights important policy implications and areas for future research.

\section{Defining and measuring informal employment Defining informal employment has never been a straightforward exercise. Depending on the actual focus of the study, the concept of informality has ranged from tax avoidance, absence of or limited social protection coverage and firm size. Indeed, many scholars hold that informal employment is a multidimensional phenomenon, with different dimensions and degrees of informality, such as the lack of a labour contract, pension plan, business registration, etc. (see, e.g. ILO 2004).}

The International Labour Office (ILO) has been the main international body for defining the informal domain. Its definition has extended from the characteristics of the firms to include the 
Table 1 The informal economy, various years

\begin{tabular}{lccc}
\hline Region & \multicolumn{3}{c}{ Informal economy as \% GDP } \\
& $\mathbf{1 9 8 9 / 9 0}$ & $\mathbf{1 9 9 9 / 2 0 0 0}$ & $\mathbf{2 0 0 2 / 3}$ \\
\hline OECD (21 countries) & 13.2 & 16.8 & 16.3 \\
Greece & 22.6 & 28.7 & 28.2 \\
United States & 6.7 & 8.7 & 8.4 \\
Central European and former Soviet Union countries (25) & - & 38.1 & 40.1 \\
Georgia & - & 67.3 & 68.0 \\
Slovak Republic & - & 18.9 & 20.2 \\
Africa (23) & - & 41.3 & 43.2 \\
Zimbabue & - & 59.4 & 63.2 \\
South Africa & - & 28.4 & 29.5 \\
South America (21) & - & 41.1 & 43.4 \\
Bolivia & - & 67.1 & 68.3 \\
Chile & - & 19.8 & 20.9 \\
Asia (28) & - & 28.5 & 30.4 \\
Thailand & - & 54.1 & 52.6 \\
Singapore & - & 13.1 & 13.7 \\
\hline Note Regional values are unweighted averages. & & & \\
Source Schneider (2002, 2006). & & & \\
\hline
\end{tabular}

characteristics of work arrangements so that informal employment is now defined as 'total number of informal jobs, whether carried out in formal sector enterprises, informal sector enterprises, or households' (ILO 2002). Informal jobs refer to work outside the regulatory framework which are not subject to labour legislation, social protection, taxes or employment benefits. Various dimensions thus determine whether a job is informal or formal, ranging from registration with social protection schemes, to compliance with labour or tax law. Several types of workers are identified as informal: own-account workers and employers of informal firms, contributing family workers, informal employees (of formal and informal firms), and members of informal producers' cooperatives.

Systematic statistics based on this broad definition are scarce as are statistics on trends in informal employment over time. In Table 1, we report statistics ${ }^{1}$ on the share of the informal economy in total output, where the informal economy is defined as unregistered activities. Although this table does not indicate the share of people engaged in the production of this output, the number of people employed in unregistered activities is obviously closely linked to this. ${ }^{2}$ Furthermore, it is important to note that involvement in the informal economy is not necessarily the same as informal employment as defined above. ${ }^{3}$ Nonetheless, the table offers some interesting information. The highest share of the informal economy is found in Africa and South America with around 42 per cent. The OECD countries rank last with a non-negligible 16.8 per cent. As the variation within each group can be considerable, the table also displays respectively the highest and lowest value per group. ${ }^{4}$ The table also shows some trends over the years: the trend is clearly an upward one. In the OECD region, where informality is lowest, its share rose from 13.2 per cent in 1989/90 to 16.3 per cent in 2002/3. However, for most regions other than the OECD, data are only available for limited time periods so that the upward trend should be interpreted with care.

\section{Informal employment: a multi-dimensional phenomenon}

Whichever definition is chosen, it is important to keep in mind that informal employment refers to many different types of workers and activities, ranging from marginal self-employed own-account workers, to well-off entrepreneurs who employ others without a contract or without paying taxes or social contributions, and from informal employees of informal or formal firms to contributing family workers. The diversity of the sector is also apparent when one looks at the phenomenon of multiple jobholding. In particular, for some people an informal 
Table 2 Primary vs. secondary informal job-holding in five countries

\begin{tabular}{lcc}
\hline & \multicolumn{2}{c}{ Informal employment as } \\
& 1st job (\%) & 2nd job (\%) \\
\hline Barbados & 88.6 & 11.4 \\
Georgia & 97.2 & 2.8 \\
Kyrgyzstan & 97.6 & 2.4 \\
Lithuania & 77.5 & 22.5 \\
Russian Federation & 79.9 & 20.3
\end{tabular}

ILO (2002). Data are for 1998-2001.

job is the only source of income, while for other informal work can be a complement to formal job earnings. In such cases, people combine a formal job or formal business with a small informal business or informal wage work. While it is well established that multiple job-holding of this kind is widespread, it is hard to establish the extent of the phenomenon as household and labour force surveys often do not capture the existence of several jobs.

Table 2 shows, for a limited number of countries, whether informal work is performed as main or as secondary activity. In some countries an important share of people is engaged in informal employment in addition to their formal job. This is as high as 22.5 per cent in Lithuania and 20.3 per cent in Russia. In some other countries, such as Georgia and Kyrgyzstan, this share is much lower.

It is important to note that the overlap between formal and informal activities is even more pronounced if we take the household or the family as the unit of analysis. Many families decide on the division of labour within the household on the basis of expected returns and choose a 'smart' combination of informal and formal work along with other forms of income-generating and riskmanagement activities (e.g. migration). Such a household strategy makes particular sense if one household member's formal job offers formal sector benefits to the entire family, thereby reducing the worth of such benefits for other members.

Studies show that a non-negligible share of the labour force over time moves between the formal and informal sectors and unemployment. This phenomenon is often studied in relationship to business cycles. Conventional economic theory predicts a movement of workers into informal employment in times of recession, and a decrease once the economy recovers and formal employment takes up. Although the evidence generally shows a growth of informal employment when the economy contracts, there is also evidence of movements into the informal sector in booms. It may be that tight labour markets lead workers to look for better jobs during such periods and to take the risk of starting a (informal) business. Indeed, these moves from formal to informal self-employment can very well go hand in hand with increases in earnings (see, e.g. Packard 2007; Duryea et al. 2006; Bosch and Maloney 2006).

Such findings challenge the traditional view of informal economy as always a last resort for workers who cannot find a formal job. Informal employment, particularly self-employment, is not necessarily considered the least best option. Various elements have to be considered in order to detemine whether workers are better or worse off in their respective jobs. One obvious element is earnings. While it is generally the case that informal employment is associated with lower earnings than formal employment (Chen et al. 2004; Perry et al. 2007; Gasparini and Tornarolli 2007; Bosch and Maloney 2006), this aggregate phenomenon conceals some interesting particularities. As mentioned above, studies on gross worker flows show that moves from formal employment to informal self-employment can very well go hand in hand with higher earnings. This type of evidence is most frequently reported in Latin America.

Non-monetary elements also play a role. Although there is still very little systematic information on this, there have been some interesting recent studies on job satisfaction and happiness of workers by employment category, again mainly from Latin America. Studies from Argentina, Bolivia, Colombia and Dominican Republic show that a considerable percentage of the informal self-employed in these 
countries value the autonomy, flexible working hours and good prospects associated with their work status. In addition, 30.3 per cent of the men and 37.4 per cent of the women in informal salaried work in a Brazilian study reported that they did not want to quit their informal job for a job with a work contract (all studies quoted in Perry et al. 2007).

Such evidence suggests that earnings vary among informal workers according to their employment status and that some are better off than formal workers while others are clearly worse off (Günther and Launov 2006; Maloney 1999; UNIFEM 2005). Figure 1 in Chen in this IDS Bulletin uses a pyramid diagram to convey some of the differences in the earnings status of different groups in informal employment. It suggests that employers are likely to be among the better off in the informal economy while groups such as homeworkers are likely to be worst off. The figure also highlights the gender distribution of work in the informal economy with men better represented at the top of pyramid (employers, micro-entrepreneurs) while women are more likely to be found at the bottom, working as unpaid family workers and homeworkers.

\section{The evidence on informal employment in Mexico and China: raison d'être and policy implications}

The factors behind the persistence or growth of informal employment have been the subject of considerable debate. Chen et al. (2001) distinguish between three different schools of thought (see also Chen, this IDS Bulletin). The dualist school views the informal sector as comprising marginal activities, distinct from and not related to the formal sector, which provide incomes for the poor and safety nets in times of crisis. The legalist school suggests that entrepreneurs opt to operate informally in order to avoid the costs, time and efforts associated with formal registration. Finally, the structuralist school argues that informal enterprises and their workers are subordinated to large capitalist firms, reducing their input and labour costs, and enhancing their competitiveness. Informality in this view is a logical condition of capitalist production. The rise of informality in this view reflects global processes of economic and trade liberalisation and flexibilisation of work relations.

In reality, bits and pieces from different theories are often needed to describe and explain country level evidence. China and Mexico are interesting examples for illustrating the heterogeneity of informal employment. Whereas in both countries a substantial part of the population is engaged in informal work, the rationale behind this phenomenon differs substantially between the two countries. ${ }^{5}$

In Mexico, it is estimated that roughly one-third of the economically active population are working informally. This is one of the highest figures among OECD countries. Some authors argue that this informality is the product of excessive regulations (red tape, labour codes), low quality of services and high social security contributions in the formal sector that lead people to prefer an informal over a formal job (Perry et al. 2007). Along the same line, they also hint at the various social programmes and instruments implemented in Mexico for those working informally that further reduce the incentive for formalisation. All this, they argue, leads to a drag on the country's productivity as informal firms have a lower productivity than formal ones (Levy 2007).

The story in China is very different. It has had sustained growth at nearly double-digit numbers for more than 10 years now. This growth pattern has been accompanied by an impressive rise of the informal sector. It is estimated that today roughly 50 per cent of the total urban employment is informal, using various different definitions and accounting exercises (Cai and Wu 2006). Migrants make up about 80 per cent of those working without regular and registered contracts (Du et al. 2006). Because many of these migrants continue to have their hukou in rural areas, they are automatically classified as informal when they take up a job in the city. The informal sector is characterised as a highly dynamic and productive sector, but also offering lower wages, less security, longer working hours and sometimes bad, and even abusive, working conditions. According to a recent report by the World Bank (2007) three factors drive the development of the informal sector: the continuous development of a self-employed small business sector, particularly in trade and services; the inflow of migrants from rural areas; and a huge number of laid-off workers from formally state-owned enterprises. The report also flags regulations (migration, labour) as well as the limited availability and scope of formal safety nets as contributing to increasing informal employment. Finally, globalisation and the subsequent increased demand for labour- 
intensive product exports, have led to the increased demand for unskilled labour, mainly provided by rural migrants in cities.

The current view on the role of the informal sector, and more specifically informal employment for Chinese development, is seen more in positive rather than negative terms (World Bank 2007; MoLSS 2002). Hu (2004, 2006) argues that urban informal employment growth since the early 1990s is the main driving force of job creation and urbanisation. The massive lay-off of persons employed in the formerly state-owned enterprise would have caused much more social and political problems had the informal sector not provided some sort of saftey net and, for some workers, even an opportunity to move out of poverty. Hence, the informal sector is seen as extremely flexible, dynamic and innovative and it has acted as a safety net for all those who moved to cities or have been laid off to find at least some income-earning possibilities. Moreover, the informal sector in China is treated as part of the national economy and is to some extent subject to government regulations and management. Ruffer and Knight (2007) argue that informal labour markets in China are subject to competitive forces, more so than the formal labour markets. However, informal employment does not come without specific problems and challenges that call for immediate policy attention and intervention. There are important issues to be resolved with respect to workers' social protection and working conditions, and most importantly the question about social cohesion and social integration of rural migrants, a large group of those informally employed.

The comparison between China and Mexico reveals several interesting points, in particular with respect to their differences. First, the origins and raison d'être for informal employment differs. In China the development of informal employment is a somewhat recent phenomenon related to the surge in the demand for labour in the booming parts of the country. It is thereby also quite closely linked to migration and the informal sector is quite integrated into the economy acting as a huge labour reservoir. In Mexico, on the other hand, it has been in existence for quite a long time and is perceived to exist in parallel with the formal economy. Second, views about the impact of the informal sector differ between the two contexts. In China, it is seen as the backbone of the growth miracle while in Mexico, it is viewed as a product of the country's low growth rates. Third, in China a large majority of those informally employed are wage or own-account workers, many of them migrants with their hukou in rural areas and hence have very little choice to become formal. In Mexico in contrast, a substantial part of those working in the informal sector could switch to formal work. Studies (Bosch and Maloney 2006; Rodríguez-Oreggia 2007) have shown that there is substantial movement from informal to formal employment and vice versa. About 15 per cent of informal wage workers switched to formal wage work between 2003 and 2004 according to a study by Rodríguez-Oreggia (2007). Fourth, while in China the informal sector seems to be to a good extent under the control of the government and is somewhat regulated, this is not the case for Mexico.

Besides these differences, there are also some common challenges that both countries face in relation to informal employment. In both countries informal employment will continue to be important for a while and there is huge scope for developing policies that will simultaneously promote its positive aspects and counterbalance its negative ones. For example, the high level of informalisation in China makes it extremely difficult for the government to develop comprehensive social security schemes, leaving a lot of people vulnerable against income shocks and excluded from the social, political and economic life, and contributing to raising inequality. The design of these programmes has to be done carefully, though, to avoid perverse incentives preventing a further formalisation of the economy leading to huge fiscal problems. In particular, the financing of social contributions of the migrants and their families who still have their hukou in a rural area poses a huge challenge for urban communities as they do not necessarily get transfers from the central government. A better integration of employment, social protection and migration policies is called for and will most likely require important changes in the institutional set-up.

The Mexican examples of Seguro Popular and Oportunidades show that it is possible to reach out to those parts of the population and to provide some basic access to healthcare and social protection. This might, however, come at the cost of reduced growth: according to Levy (2007) 'social programs can reduce productivity and growth as they inadvertently generate perverse incentives for 
workers and firms'. The point - Levy argues - is that households and individuals voluntarily choose to stay informal, get access to social programmes while evading payment of taxes and social security contributions. Social programmes that led to a reduced total factor productivity alongside a reduction in public investment has led to the disappointing growth performance in Mexico, Levy concludes.

Whereas the issue of mobility between the formal and informal sector is hotly debated, there is more consensus on the need for policy instruments that provide incentives for becoming formal. Besides cutting red tape in bureaucracy and improving tax incentives, there is a definitely a need for quality improvement of services to entrepreneurs. Better access to credit, information and training for entrepreneurs who are considering becoming formal might be one way to go. Both countries show the need for overcoming the existence and artificial divide between policies that focus on either the formal or informal or that focus on social protection or employment creation alone. These aspects have to be brought together to achieve more coherent policies.

\section{The emerging agenda: challenges for policy and research}

Observations that informal employment does not necessarily decline in the context of economic growth so that growth alone will not formalise employment; that there is considerable heterogeneity of jobs and working conditions within the informal sector; and that the line between the formal and informal work is increasingly blurred all question the relevance and effectiveness of existing labour market, employment and social protection policies. On the one hand, benefits to informal workers and the self-employed are mostly provided by social assistance programmes which target poor individuals and households. On the other hand, individuals working formally are basically covered by labour market and social protection policies, designed specifically for those in formal employment. This creates a clear-cut dichotomy in the types of policies directed towards people in formal and informal employment. There is a need to develop innovative labour market and social protection policies for those working informally beyond the classical 'social assistance approach'. Our review of the evidence on informal work suggests an emerging agenda for policy and research.

\subsection{Improving data collection}

We have highlighted new evidence and the trends they suggest in our discussion. However, much is still unknown. Existing datasets are scattered, often of a very low quality and outdated. Information on multiple job-holding is scarce; most data do not cover this topic. Improving statistics and measurement tools to properly assess labour market conditions is crucial for informed policymaking. Once data collection and quality is taken care of, better indicators can be constructed to capture the realities on the ground. ${ }^{6}$

\subsection{Understanding realities on the ground}

There is a need to analyse in greater depth the determinants of informal employment. In many Latin American countries, it is clear that some people opt out of the formal systems; however, it is not yet known what fraction of those working informally do so voluntarily. To understand what is voluntary about informal employment, we have to know what alternatives people might have. For Latin America we have some information on these questions, based on detailed data surveys. However, this information is missing for most other regions of the world.

Leading questions could be: is there a pattern in the size and composition of informal employment in low- and middle-income countries? What can we say about the factors influencing this pattern, for example trade openness, labour market regulation, institutional environment and history? What keeps some people excluded from formal employment? What determines individual choices? Do all people have the same choices about where they work? We know from the evidence that not everyone in the informal sector is worse off than those in the formal sector. We need to understand better why different groups within the informal sector, such as the selfemployed, wage employees, women, men and youth, choose to remain within it or to move out. At the same time, it is also clear from the available evidence that some people do not have any choice other than staying informal. They include the poor and uneducated and the socially marginal groups in society. We need to better understand what keeps them in informal employment and how we can remedy the bottlenecks they face. Finally, we need to undertake a dynamic analysis in order to be able to detect causalities. Of particular interest are the formal-informal linkages as well as the interaction between self-employed and wage employed within informal employment. 


\subsection{Identifying better policies, instruments and good practices to handle trade-offs}

Three points emerge out of our discussion with regard to the policy agenda. First, there is a need for a holistic assessment of the impact of informal employment on the economy. It is clear that sometimes, from an individual perspective it makes sense to stay informal - but from a societal perspective it is clearly not. To develop a favourable business environment and adequate public services, a certain formalisation of the economy is needed. The critical question here is: how to do it? Many examples show that an aggressive formalisation can lead to the opposite result. For example, when, in the mid-1990s, the authorities of Mexico City sought to ban all informal street vending in the historical centre, only a fraction of those vendors actually switched to a formal market setting; a large portion simply continued their informal trading in other areas of the city, or had to close their business, becoming even more vulnerable. It is a very important step forward to identify the right set of incentives through a critical review of good practices and a good understanding of realities on the ground.

Second, and following the same line of argument, do the existing policies and instruments of

\section{Notes}

* The authors would like to thank Christian Morrisson, Jacques Charmes and Bill Maloney for very useful comments on an earlier draft. This article has also benefited from comments received from participants at the IZA/World Bank second conference on 'Employment and Development', held in Bonn in 2007, as well as the 'Work and Well-Being' conference organised by the University of Bath. (This article is a shorter version of the OECD Development Centre Working Paper 266. The authors are grateful to Naila Kabeer, Jacques Charmes, Bill Maloney, Christian Morrisson and Uma Rani for very useful comments on an earlier draft.)

1 The figures are estimated through indirect methods based on physical inputs (e.g. electricity use), currency demand or a model approach combining several factors. See Schneider 2002 for a more thorough presentation. A more critical account of the use of these methods can be found in Breusch 2005. developing countries, as well as of donor agencies, take into account the changing and heterogeneous realities on the ground? As an example, it is often not understood that the appropriate unit for risk management is not the individual, but the household or family. Often members of families are allocated strategically between formal and informal employment. This has important consequences for providing the right incentives, for offering appropriate services to informal business, as well as for setting up social protection mechanisms for those in informal employment.

Finally, there is a need to differentiate between different regions of the world and between low-middle- and high-income countries. In the lowincome context the formal sector is too small to provide jobs for all but a small minority of the working population. The critical challenge here is the transformation of a low labour productivity economy, mostly based on agriculture, to one based on labour-intensive manufacturing, and services. In middle-income countries the challenges are quite different. Here, there is a need to improve formal and informal linkages to create a conducive business environment and to allow for a better social protection of those currently not covered.

2 The share of informal employment in total employment is surely a higher percentage than the share of the informal economy in total output, as on average informal work is less productive than formal work.

3 For example, the informal economy comprises illegal activities, which are not informal employment.

4 In case the ranking changes over time, we display the country with the lowest/highest informal economy share in the latest year available.

5 This section draws on the OECD Development Centre's work programme on work and wellbeing, in which Mexico, China and Romania figure as country studies.

6 The World Bank together with the University of Cornell has started an interesting project to revise and test new indicators, and more initiatives of this kind are most welcome. 


\section{References}

Bosch, Mariano and Maloney, William F. (2006) Gross Worker Flows in the Presence of Informal Labour Markets. Evidence from Mexico, 1987-2002, World Bank Policy Research Working Paper 3883, Washington DC: World Bank

Breusch, Trevor (2005) 'Estimating the Underground Economy Using MIMIC Models', Econometrics 0507003, EconWPA, revised 25 July

Cai, Fang and Wu, Yaowu (2006) 'Informal Employment in Urban China: Size and Characteristics', Background Paper for the World Bank Labor Markets Development Program, August 2007

Chen, Martha Alter; Jhabvala, Renana and Lund, Francie (2001) 'Supporting Workers in the Informal Economy: A Policy Framework', paper prepared for ILO Task Force on the Informal Economy, November

Chen, Martha Alter; Vanek, Joann and Carr, Marilyn (2004) Mainstreaming Informal Employment and Gender in Poverty Reduction. A Handbook for Policymakers and Other Stakeholders, Ottawa: International Development Research Centre

Du, Yang; Cai, Fang and Wang, Meiyan (2006), 'Marketization and/or Informalization: New Trends of China's Employment in Transition', paper prepared for the World Bank Labor Markets Development Program, August 2007

Duryea, Suzanne; Gustavo Marquez, Carmen and Scarpetta, Stefano (2006) For Better or For Worse: Job and Earnings Mobility in Nine Middle- and LowIncome Countries, Washington DC: Brookings Trade Forum

EC (2007) Promoting Employment through EU Development Cooperation, European Commission Staff Working Document, Brussels: European Commission

Fields, Gary (2005) A Guide to Multisector Labour Market Models, World Bank Social Protection Discussion Paper Series 0505, Washington DC: World Bank

Gasparini, Leonardo and Tornarolli, Leopoldo (2007) Labour Informality in Latin America and the Caribbean: Patterns and Trends from Household Survey Microdata, CEDLAS Working Paper, CEDLAS, Argentina: La Plata

Gindling, Tim (1991) 'Labor Market Segmentation and the Determination of Wages in the Public, Private-Formal and Informal Sectors in San-Jose, Costa-Rica', Economic Development and Cultural Change 39.3: 585-605
Günther, Isabel and Launov, Andrey (2006) Competitive and Segmented Informal Labour Markets, IZA Discussion Paper 2349, Bonn: Institute for the Study of Labor

Harris, John R. and Todaro, Michael P. (1970) 'Migration, Unemployment and Development: A Two-Sector Analysis', The American Economic Review 60.1: 126-42

Hart, Keith (1973) 'Informal Income Opportunities and Urban Employment in Ghana', Journal of Modern African Studies 11.1: 61-89

Hu, Angang (2006) The Emergence of Informal Sector and the Development of Informal Economy in China's Transition: A Historical Perspective (1952-2004), http://siteresources. worldbank.org/INTDECABCT OK2006/Resources/H-__Angang.ppt (accessed 27 February 2008)

$\mathrm{Hu}$, Angang (2004) 'Economic Growth and Employment Growth in China (1978-2001)', Asian Economic Papers, spring/summer 2004 3.2: 166-76

ILO (2004) Economic Security for a Better World, ILO Socio-Economic Security Program, Geneva: International Labour Office

ILO (2002) ILO Compendium of Official Statistics on Employment in the Informal Sector, ILO STAT Working Paper 1-2002, Geneva: International Labour Office

Islam, Rizwanul (2004) The Nexus of Economic Growth, Employment and Poverty Reduction: An Empirical Analysis, Geneva: International Labour Office

Kenya Report (1972) Employment, Incomes and Equality: A Strategy for Increasing Productive Employment in Kenya, Geneva: International Labour Organization (ILO)

Levy, S. (2007) 'Can Social Programs Reduce Productivity and Growth? A Hypothesis for Mexico', paper written for the 8th Global Development Network Meeting in Beijing, 12-19 January

Lewis, W.A. (1954) 'Economic Development with Unlimited Supplies of Labor', Manchester School of Economic Studies 22: 139-91

Lundström, Susanna and Ronnås, Per (2006) Integrated Economic Analysis for Pro-Poor Growth, SIDA Methods document, Stockholm: Swedish International Development Cooperation Agency (SIDA)

Maloney, William F. (2004) 'Informality Revisited', World Development 32.7: 1159-78

Maloney, William F. (1999) 'Does Informality Imply Segmentation in Urban Labor Markets? Evidence from Sectoral Transitions in Mexico', The World Bank Economic Review 13.2: 275-302 
Mead, Donald C. and Morrisson, Christian (1996) 'The Informal Sector Elephant', World Development 24.10: 1611-19

MoLSS Ministry of Labor and Social Security (2002) Labor and Social Security in China, White Paper, April, Beijing, China: State Council

OECD (2006) Promoting Pro-Poor Growth. Policy Guidelines for Donors, Paris: Organisation for Economic Cooperation and Development Osmani, S.R. (2005) The Role of Employment in Promoting the Millennium Development Goals, Working Paper 18, Issues in Employment and Poverty, Geneva: ILO/UNDP

Packard, Truman G. (2007) Do Workers in Chile Choose Informal Employment? A Dynamic Analysis of Sector Choice, World Bank Policy Research Working Paper 4232, Washington DC: World Bank Perry, Guillermo E.; Maloney, William F.; Anas, Omar S.; Fajnzylber, Pablo; Mason, Andrew D. and Saavedra-Chanduvi, Jaime (2007) Informality: Exit and Exclusion, Washington DC: World Bank Rodríguez-Oreggia (2007) La Dinámica Comparativa del Sector Informal en México, Working Paper, Mexico: Universidad Iberoamericana
Ruffer, Tim and Knight, John (2007) 'Informal Sector Labour Markets in Developing Countries', Oxford Policy Management, February

Schneider, F. (2006) 'Shadow Economies and Corruption all Over the World: What do we Really Know?' paper presented at the 8th INFER Annual Conference, Cork, Republic of Ireland, 22 September 2006

Schneider, F. (2002) 'Size and Measurement of the Informal Economy in 110 Countries Around the World', paper presented at workshop of Australian National Tax Centre, Canberra, Australia, 17 July 2002

UNIFEM (2005) Progress of the World's Women 2005 Women, Work and Poverty, New York: United Nations Development Fund for Women World Bank (2007) China's Modernising Labour Market: Trends and Emerging Challenges, Synthesis Report for the ESW Component of the China Labor Market AAA Program, August 